\title{
The Meaning-shift Unit of Chinese Intensifiers: A Corpus-based Study*
}

\author{
Guobing Liu \\ Faculty of International Studies, Henan Normal University, Xinxiang, China \\ Xiaolian Zhang \\ Faculty of International Studies, Henan Normal University, Xinxiang, China
}

\begin{abstract}
Meaning-Shift unit put forward by John Sinclair is the latest theory of meaning in corpus linguistics in the early 21st century. In this paper, it aims to analyze the meaning units of wanquan, in an attempt to shed light on whether Meaning-Shift unit is valid to account for the behavior of such a Chinese intensifier. The result illustrates that Meaning-Shift unit is influenced by the categories of co-selection, in which semantic prosody plays a decisive role, and that wanquan has four types of Meaning-Shift units, each of which has a canonical form and several possible variants.
\end{abstract}

Index Terms-meaning-shift unit, corpus linguistics, intensifier, co-selection, semantic prosody

\section{INTRODUCTION}

Meaning-Shift unit (MSU), the most innovative development to corpus linguistics, was put forward by John Sinclair (Sinclair, 2007; 2010) who spent his whole life in search for meaning in authentic texts. Compared with his previous studies such as idiom principle and open-choice principle, phraseological tendency and terminological tendency, extended unit of meaning, etc. (Sinclair, 1991; 1996; 2004), one idiosyncratic nature that MSU share is meaning is changeable in the process of communication. Generally speaking, MSU can be summed up in the following three major parts. First, extended unit of meaning (EUM) shall be used as the research approach. In EUM the core and semantic prosody are obligatory categories, while collocation, colligation and semantic preference are optional ones. The core can also be called as node word. It is closely related with collocation, colligation, semantic preference and semantic prosody on lexical, grammatical, semantic and pragmatic levels respectively. Importantly, semantic prosody plays a pivotal role in the identification of attitudinal meanings, serving as an indicator of speakers' or writers' communicative purposes (Louw, 1993; Sinclair, 1996; 2004; Stubbs, 2009). Second, the units of meaning are determined by the co-selection mechanism. Meaning units are strongly associated with repetition and co-occurrence of phrases rather than with specific words (Sinclair, 2008:10). The ambient meaning will shift by some categories of co-selection (Sinclair, 2007:3), that is to say, each new combination of words will have an influence on the original meaning (Cheng et al., 2008). But due to the decisive impact of semantic prosody (Sinclair, 2010; Gao and Wei, 2017:19), it is significant to interpret it in local contexts (Partington, 2004; O'Halloran, 2007; Bednarek, 2008a). Third, local grammar is a new method to describe meaning units. Sinclair (2010:42) claimed that every word apart from individual words and fixed phrases should have its own local grammar. Different from previous methods to local grammar (Hunston and Sinclair, 2000; Barnbrook, 2002; Allen, 2005; Bednarek, 2008b; Su, 2015), the theory elaborated at this point does not starts from specific meanings but from specific words in texts. Specifically, it starts from structuralizing a lexical item, and then describes its meanings from both lexical and grammatical levels in local contexts (Gao and Wei, 2017:19).

The theory of MSU provides a clear way to study meaning, the most important theme in corpus linguistics. It first focuses on a specific lexis, then classifies the canonical forms and their variants through the co-selection mechanism, and eventually excavates the internal meanings along with the discoursal functions. A great number of works have mushroomed since 2007 when the MSU theory was proposed. For example, Cheng et al. (2008) provided an analytical procedure using ConcGram to identify meaning-shift units, which casts light on later studies (see Wray, 2012; Gao and Wei, 2017). However, a close look at the present situation of linguistics in China indicates that the MSU theory doesn't receive enough attention. Gao and Wei (2017) are the first researchers who introduced the theory to China. They not only discussed the core implication and the analytical procedure of Meaning-Shift unit, but also took the verb POSE as an example to demonstrate how it worked. Li (2018) emphasized the importance of context and analyzed the local grammars by analyzing the verb SEVER and the phrase 'what a(n) N'. Lu and $\mathrm{Wu}$ (2019) made a contrastive analysis between Chinese and English popular phrases on their regularity and mechanism of MSU from a diachronic perspective. Surprisingly, most studies have been conducted to uncover the characteristics of English language. In this paper, we attempt to shed light on whether Meaning-Shift unit is valid to account for the behavior of Chinese language, such as

\footnotetext{
* This research was supported in part by Henan Planning Office of Philosophy \& Social Sciences with the Project of Philosophy and Social Sciences (Project No.: 2020BYY007).
} 
‘完全’ (wanquan), an intensifier, which is analogous to completely or totally in some sense.

\section{PRevious Studies OF INTENSIFIERS}

Language researchers do not have a precise definition of intensifiers. For example, Bolinger (1972:17) described intensifiers as a gradable system of some specific properties, which had a reinforcing or lowering effect. According to Labov (1984:43), intensifiers were the kernel of social and emotional expressions with a gradient feature. Quirk et al. (1985) and Crystal (2011) considered intensifiers as adverbs whose function was to aggravate or mitigate the components of sentences. Nevertheless, there comes to one unanimous proposition that intensifiers have some semantic functions like strengthening tones and highlighting information. Intensifiers in general identify two broad types of meanings by which functional assessment may be conveyed: one is amplifiers and the other downtoners (Quirk, 1985:589). The former, as the name implied, amplifies discoursal functions, such adverbs as absolutely, totally, completely, etc. in English and '十分' (shifen), ‘完全' (wanquan), ‘非常' (feichang), ‘最' (zui) and so on in Chinese; while the later truncated the discoursal meanings, such adverbs as slightly, part of, enough, etc. in English and '稍微' (shaowei), ‘有些' (youxie), ‘略' (lïe) and so on in Chinese. More specifically, amplifiers can be divided into two subsets, namely maximizers and boosters, while downtoners comprise four subsets, e.g., approximators, compromisers, diminishers and minimizers (Quirk, 1985:589). These intensifiers are on a continuum of degree, that is, their distinction is not easy to make (Kennedy and McNally, 2005).

The empirical studies on intensifiers at home and abroad conclude the following five aspects. (1) Intensifiers' syntactic structures and categories. For instance, Bolinger (1972) suggested that most intensifiers were lexical items, covering 'relatively grammaticized' and 'relatively ungrammaticized', while non-lexical intensifiers involved prosodic devices or repetitions. Quirk et al. (1985) considered intensifiers should not be restricted to those having an increase in intensification, but refer to an abstract intensity scale, which could be relatively low or high and could also be applied to a predicate or part of a predicate. (2) Synchronic and diachronic studies on intensifiers. For instance, Ito and Tagliamonte (2003) summarized the historical trajectory of language changes by investigating intensifiers from 12th century to 20th century. Tagliamonte and Roberts (2005) analyzed the usage of intensifiers in Friends, one of the American popular television series, and predicted that media language was a token for innovative words. Partington (1993) made a survey on changes of meanings and functions of intensifiers like very, utterly, etc. from both synchronic and diachronic perspectives. (3) Social factors affecting the use of intensifiers. Lakoff (1975) pinpointed that women compared with men were more inclined to use intensifiers even though they were treated as a vulnerable group. Tagliamonte (2008) did a survey on what intensifiers Torontonians normally used, which indicated that the intensifier system may be influenced by social factors like age and sex. Xiao and Tao (2007) explored the variations of 33 amplifiers from BNC corpus within extra-linguistic parameters, bringing sociolinguistic concerns to corpus-based studies. (4) The collocational or collo-structional analysis measuring the relationship between adjectives and intensifiers (or intensifier constructions). Altenberg (1991) analyzed the repeated collocates of intensifiers in London-Lund Corpus of Spoken English, showing that the adjectives modified by intensifiers were also gradable, which were largely dependent on the intensifiers' categories. Kennedy (2003) investigated the collocational relation between intensifiers and their companying words, and found some specific grammatical and semantic features. Shao et al. (2017) adopted a collostructional analysis to calculate the collostructional strength between adjectives and the 'amplifier + adjective' construction by utilizing cluster analysis and correspondence analysis, which proved that such way was mighty to distinguish the nuances of difference between intensifiers and their collocates. (5) Intensifiers' semantic prosody and preference. Louw (1993) found that the right collocates of intensifiers usually carried bad meanings, thus infecting the whole context becoming negative. Tao (2007) took utterly as an example to study its linguistic features and found that it could be used as a modifier or as a discourse marker, symbolizing a positive prosody in general. Su (2016) investigated how second language learners used intensifiers from both semantic and sociolinguistic perspectives, the result of which indicated that Chinese English learners had different understandings towards intensifiers compared to native speakers. In short, the studies exemplified above concentrate on English intensifiers and have made innumerable achievements. However, few researches have been carried on Chinese language, let alone to use the MSU theory as the starting points. Thus, we are going to select a Chinese intensifier as our research object, with the aim to enrich the theoretical connotation of Meaning-Shift unit and broaden its empirical research areas.

\section{DATA AND METHOD}

\section{A. Research Questions}

This study seeks to address the following two questions:

(1) What is the relationship between frequency and the MSUs concerning the intensifier wanquan?

(2) How many MSUs does wanquan have and what are the canonical forms and their variants respectively?

\section{B. Corpus}

The corpus we used is from the Chinese National Corpus (the CNC, also known as Guojia Yuwei Yuliaoku), comprising nearly 100 million Chinese characters. It covers three main territories over the past hundred years, namely 
social sciences, natural sciences, and miscellany, which gives a vivid description of Chinese language in the modern society. This corpus is available online (http://corpus.zhonghuayuwen.org/). We first got 4,184 concordance lines of wanquan in total from the website and saved them in TXT format. Secondly, we extracted 500 concordance lines randomly by Conc_Sampler (Liang et al., 2010). After manual inspection, however, 455 desirable concordance lines were left. Lastly, PowerConc 1.0 was utilized to discover the linguistic features of the Chinese intensifier.

\section{Research Method}

Since meanings are achieved by phrases rather than lexical items, units of meaning will arise from recurrent word sequences or the co-selection of words (Sinclair, 2008). Cheng et al. (2008) following Sinclair's step proposed an analytical procedure to continue finding meaning units. The procedure concludes four steps: (1) make an analysis of the core in concordance lines through EUM, not only identifying its text configurations but also counting their frequency; (2) search for the canonical forms based on frequency and identify their meanings; (3) classify the variants according to configurations' semantic prosody; (4) draw a conclusion on the Meaning-Shift units of the core. This study will use such procedure to recognize the MSUs of wanquan, trying to demonstrate the feasibility of the MSU theory in Chinese language.

\section{RESULTS AND DISCUSSIONS}

\section{A. Co-selection}

Co-selection means speakers select words that share same discoursal features in daily communication (Morley and Partington, 2009:139), the purpose of which is to produce units of meaning (Sinclair, 1987; 2004). Wei (2012:1) elaborated the notion in three aspects - co-selection of lexis and lexis, co-selection of lexis and grammar, and co-selection of pattern and meaning. Extended meaning unit, the basic element of Meaning-Shift unit, is the paradigm to conduct researches on co-selection, which consists of five categories, e.g., the core, collocation, colligation, semantic preference and semantic prosody. The core is the word we put our focus on, which is an indispensable part of meaning units. Collocation is the co-occurrence of words companying the core whilst colligation is concerned with word class around it. Semantic preference refers to items restricted by their lexical fields, that is, these items constitute the main topics of texts. Semantic prosody shares equal status with the core, both of which are essential to this theory, and it's also an indication of the core's overall meaning in specific contexts. Here we take wanquan as an example to demonstrate the characteristics of co-selection under the EUM theory. The list below merely enumerates the typical and high-frequency phrasal items.

(1) The Core: 完全 (wanquan)

(2) Collocation: 不同 (butong), 相同 (xiangtong), 可以 (keyi), 不能 (buneng), 没有 (meiyou), 正确 (zhengque), 相反 (xiangfan), 问题 (wenti)

(3) Colligation: 1) Animate subject: 他们 (tamen), 他 (ta), 她 (ta), 我 (wo), 自己 (ziji)

2) Inanimate subject: 这 (zhe), 它 (ta), 目的 (mudi), 原则 (yuanze)

3) Notional verb: 脱离 (tuoli), 沉浸 (chenjin), 改变 (gaibian)

4) Adjective: 一样 (yiyang), 正确 (zhengque), 相反 (xiangfan)

5) Negative word: 不 $(b u)$, 不能 (buneng), 没有 (meiyou)

6) Link verb: 是 $(s h i)$

(4) Semantic Preference: 问题类 (wenti lei), 比较类 (bijiao lei), 陈述类 (chenshu lei)

(5) Semantic Prosody: 客观描述事物、事件和实验现象 (keguan miaoshu shiwu, shijian he shiyan xianxiang), 朝 向积极方向发展 (chaoxiang jiji fangxiang fangzhan), 出现不好结果 (chuxian buhao jieguo), 提供解决方案 (tigong jiejue fang'an)

It is suggested that the Chinese intensifier have complex patterns of behavior, whose primary function is to be an adjunct which modifies adjectives, denoting the thorough degree and the overall scope. Sometimes, it occurs in comparative sentences. The subjects in '完全' patterns are mostly inanimate, such as pronouns like '这' (zhe: this, which means it pronounced as zhe in Chinese, and literally means this in English), “它' (ta: it) and '目的' (mudi: purpose), ‘原则’ (yuanze: principle), “心情' (xinqing: feeling), “问题’ (wenti: problem), ‘方案’ (fang'an: plan), ‘筹备” (choubei: arrangement), ‘反应' (fanying: reaction), ‘思想' (sixiang: thought), etc.; when the subjects are animate, they are pronouns like ‘他们’ (tamen: they), ‘他’ (ta: he), ‘她’ (ta: she), ‘我' (wo: I), ‘自己’ (ziji: self) and ‘作者' (zuozhe: author), ‘孩子’ (haizi: child/children), ‘导游’ (daoyou: guide), ‘政府' (zhengfu: government), ‘中国人’ (zhongguoren: Chinese), etc. Obviously, such features of subjects are not in conformity with those of Chinese sentences where animate subjects outnumber inanimate ones. In addition, the concordance lines demonstrate that the core and negative words are in high occurrence. The negative words can either precede ‘完全' or follow it. In the first case, the negative words are ‘不, ‘不能”, ‘并不’, ‘并非’, ‘没有’, which are equivalent to not in English, while in the second case, the negative words are ‘不能' (buneng: cannot), ‘不了解’ (bu liaojie: not understand), ‘不同' (butong: not different), ‘不适合’ (bu shihe: not suitable), etc. Another characteristic of “完全' is that it is closely associated with the link verb “是' (shi: be) 
in order to make judgements on something. If “完全' is in the left of '是”, the “完全+是' pattern will be followed by noun groups, propositions or adjectives that transformed their word class from verbs. If “完全' is in the right of “是”, the “是十完全” pattern will be followed by adjectives, such as “一样的' (yiyangde: identical), “正确的’ (zhengquede: correct), “必要的’ (biyaode: necessary), ‘独立的’ (dulide: independent), etc. Although they have different collocates, the two patterns both function to strengthen the degree of judgements. From the above analysis, we conclude that wanquan has three semantic preferences, which are preference for problem, preference for comparison and preference for description. In accordance with these preferences, we summarize three types of semantic prosody in great detail— to describe objects, states or experimental phenomena, to develop towards positive directions, to get bad results, and to provide solutions.

\section{B. Semantic Prosody}

We chose the following sentences in the $\mathrm{CNC}$, which are all in problem situation for the purpose of finding out how co-selection works, notably the working mechanism of semantic prosody.

(1) 然而, 现实情况说明, 这个观念问题并不是完全解决了, 而是还需要在新形势下不断来解决。(ran'er, xianshi qingkuang shuoming, zhege guannian wenti bing bushi wanquan jiejue le, ershi hai xuyao zai xin xingshi xia buduan lai jiejue.)

Translation: However, the reality suggests that this conceptual problem is not thoroughly solved, which still needs to be worked out under new situations.

(2) 对于某些暂时还不能完全想通的问题, 应当作耐心细致的说服教育, 不要强迫表态, 允许有一个继续学 习, 逐步认识的过程。(duiyu mouxie zanshi hai buneng wanquan xiangtongde wenti, yingdang zuo naixin xizhide shuofu jiaoyu, buyao qiangpo biaotai, yunхи you yige jixu xuexi, zhubu renshide guocheng.)

Translation: For problems which cannot be fully understood for the moment, we should be patient and meticulous in persuasion rather than forcing to make a statement, and allow the process of persistent studying and progressive improvement.

(3) 除了那些旧社会遗留的问题以外, 大多数问题已完全不同于旧中国的情况, 不再是剥削制度的产物。(chule naxie jiushehui yiliude wenti yiwai, daduoshu wenti yi wanquan butongyu jiuzhongguode qingkuang, buzai shi boxue zhidude chanwu.)

Translation: Except for the problems left over by the old society, most of them are now completely different since they're no longer the products of the exploitation system.

(4) 但如何说明工人阶级同资产阶级存在着剥削关系, 他们之间是存在着根本利益完全相反的矛盾这一问题, 却又不能自圆其说了, 那势必要走到“修正”马克思主义关于阶级斗争的基本理论, 而陌落到修正主义的泥坑。 (dan ruhe shuoming gongrenjieji tong zichanjieji cunzai zhe boxue guanxi, tamen zhijian shi cunzai zhe genbenliyi wanquan xiangfande moudun zheyi wenti, que you buneng ziyuanqishuo le, na shibi yao zoudao "xiuzheng" makesizhuyi guanyu jiejidouzhengde jiben lilun, er duoluo dao xiuzhengzhuyi de nikeng.)

Translation: But since they cannot justify themselves on the matter that there is an exploitative relationship between the working class and the bourgeoisie, whose interests are totally opposite, there is no doubt that they will come to revise Marxist theory about class struggle, and eventually to the mire of revisionism.

The sentences demonstrated above have inanimate subjects like '问题' (wenti: problems, matter) apart from sentence (4) which is started by 'they'. In sentence (1), “完全' is part of the predicate, modifying the following verb '解决' (jiejue: solve), which expresses the meaning of [Degree: thorough]. It collocates with '解决', “问题', indicating a resolution to the conceptual problem that we shall renew our determination to work harder. In sentence (2), “完全' also has the meaning of [Degree: thorough] and of providing advice, which serves as a body of the noun group of '问题” and modifies the adjective '想通的' (xiangtongde: be understood) which is transformed from its verb form. As a part of the predicate, “完全' in sentence (3) modifies “不同于' (butongyu: be different from), which is treated as a verb in Chinese sentences, and in this sense the intensifier strengthens the degree of the difference from all angles, implying a positive meaning that the problems have a turnaround and will develop towards a good new situation. In sentence (4), prior to the adjective ‘相反的’ (xiangfande: opposite), the intensifier means [Contrast: all], which denotes a negative prosody.

When comparing sentence (1) and sentence (2), we find that both cores have a closed relationship with '问题', but their colligations are different. The former's structure is in a complete sentence, which can be presented as ' $\mathrm{N}+$ 不是 + 完 全 $+\mathrm{V}$ ', while the latter is in an uncompleted one, i.e. a noun phrase, which is “不能+完全 + Adj $+N$ '. In fact, the adjectives “想通的' in sentence (2) is a variant of the verb '想通', so that the second structure can be transformed into 'N+不能+完全 $+V$ '. Since ‘不是' and “不能' are each other's synonym, both sharing negative meanings, we conclude the two sentences own a same structure. Moreover, their semantic preferences are for '问题', and they both have the prosody of putting forward solutions to existing problems. Considering all the factors we discussed, we put the two lexical structures into one meaning unit.

Now, let's look at another different situation. The cores in sentence (3) and sentence (4) neither have similar collocates nor lexical structures. The former modifies the verb ‘不同于', whose lexical structure is '完全 $+\mathrm{V}+\mathrm{Adj}+\mathrm{N}$ ', 
while the latter modifies the adjective '相反的', having the behavior pattern of ' $\mathrm{V}+\mathrm{N}+$ 完全+Adj+N'. Although both patterns are used in the situation of comparation, there are still subtle differences. For example, the collocation of the former are certain words about the old China, and its semantic prosody is to develop towards a positive direction, whereas the latter associates closely with words about class struggle and its semantic prosody is to have an unfavorable outcome. Therefore, they belong to different units of meaning, which are called Meaning-Shift units.

To summarize, the unit of meaning is identified by the five categories of the co-selection theory. In other words, the core, collocation, colligation, semantic preference and semantic prosody make coordinated contributions to the realization of meaning units. However, only when the semantic prosody changes, will the meaning units shift accordingly. The other four categories do have an influence on discoursal meanings and functions, so sometimes their changes will incur the prosody changes, thus forming a shift of meaning unit, but sometimes they don't. Secondly, the prosody is the decisive factor to the unit of meaning. For example, in sentence (3) and sentence (4), their different prosodies make them belong to different meaning units, which further confirms that semantic prosody is in fact a unit of meaning (Gao and Wei, 2017).

\section{Textual Configuration}

The meaning units of phraseological items could be found in their repeated patterns across large text collections (Stubbs, 2009:117). Gao and Wei (2017:16) discussed that meaning units could be expressed by textual configurations, which refer to continuous word sequences, lexical grammars or behavior patterns we mentioned above. After a careful analysis, 11 textual configurations related to wanquan are summarized in 455 concordance lines. See Table I.

TABLE I.

TEXTURAL CONFIGURATIONS OF ‘完全’ (WANQUAN)

\begin{tabular}{|c|c|c|c|}
\hline No & Occurrences & Configuration & Meaning \\
\hline 1 & 119 & $\begin{array}{l}(\mathrm{Adj})+(\mathrm{N})+(\text { 不 } \mid \text { 没有 } \mid \text { 几乎 })+[(\text { 是 } \mid \text { 能 } \mid \text { 能够|可能 })+\text { 完全 }] \mid[(\text { 是 })+ \\
\text { 完全 }(\text { 地 })+(\text { 是 } \mid \text { 能 } \mid \text { 能够|可以|不 } \mid \text { 不会 } \mid \text { 没有 })]+[(\text { 被 })+(N P)+V] \mid \\
{[(\text { Prep })+(N \mid N P)+(V)+(A d j)+(N \mid N P)]}\end{array}$ & $\begin{array}{l}\text { [Scope: all] } \\
\text { subjective descriptions }\end{array}$ \\
\hline 2 & 87 & $\begin{array}{l}(\mathrm{N}|\mathrm{NP}|[\operatorname{Prep}+\mathrm{N}])+(\text { 不|不易|差不多|没有 } \\
(\text { 人 })+(\text { Prep+(Adj)+N })+[(\text { 是 } \mid \text { 能 } \mid \text { 可能 })+\text { 完全 }] \mid[\text { 完全 }+(\text { 是 } \mid \text { 能 } \mid \text { 可 } \\
\text { 以 }]+(\text { 不 })+\mathrm{V} \mid[(\text { Prep })+(\mathrm{N})+(\text { 被 })+\mathrm{V}+(\text { 是 })+(A d j)+N]|N P| \\
{[\text { Prep+Adj+N] }}\end{array}$ & $\begin{array}{l}\text { [Degree: thorough] } \\
\text { subjective descriptions }\end{array}$ \\
\hline 3 & 67 & $\begin{array}{l}(\mathrm{NP})+[(\text { 不|没有 } \mid \text { 可以 })] \mid[(\operatorname{Prep}+(\mathrm{N} \mid \mathrm{NP}))]+[(\text { 是 })+(\text { 不 } \mid \text { 不会 } \mid \text { 不 } \\
\text { 能|可能 })+ \text { 完全 }] \mid[\text { 完全 }+(\text { 是 } \mid \text { 不 })]+(\operatorname{Prep}+\mathrm{N})+\operatorname{Adj}|\mathrm{N}| \mathrm{NP} \mid \\
{[\mathrm{V}+(\mathrm{N})] \mid[\mathrm{Adj}+\mathrm{N} \mid \mathrm{NP}+(\mathrm{V})]}\end{array}$ & $\begin{array}{c}\text { [Contrast: all] } \\
\text { subjective descriptions }\end{array}$ \\
\hline 4 & 51 & $\begin{array}{l}(\mathrm{N} \mid \mathrm{NP})+[(\text { 不 } \mid \text { 不是|没有 } \mid \text { 并非 } \mid \text { 可以 })] \mid \\
{[((\text { 使 })+\mathrm{Prep}+\mathrm{N})]+(\mathrm{V})+[(\text { 是|可能 })+\text { 完全 }+(\text { 没有 })] \mid[\text { 完全 }+(\text { 是 } \mid \text { 没 }} \\
\text { 有 })]+(\operatorname{Prep}+\mathrm{N})+[(\text { 可以|能够|有机会 } \mid \text { 有可能 })+V+(A d j)+(N \mid \\
N P)]|[(A d j)+N \mid N P]| A d j\end{array}$ & $\begin{array}{l}\text { [Degree: thorough] } \\
\text { positive development }\end{array}$ \\
\hline 5 & 46 & 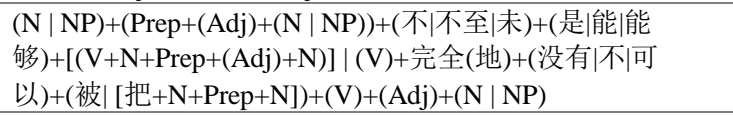 & $\begin{array}{l}\text { [Degree: thorough] } \\
\text { bad results }\end{array}$ \\
\hline 6 & 20 & $\begin{array}{l}(\mathrm{N})+[(\operatorname{Prep}+(\mathrm{N} \mid \mathrm{NP}))+[(\text { 能够|是|不 } \mid \text { 未 } \mid \text { 不能 })+\text { 完全 }+(\text { 能 })+(\mathrm{V})] \mid \\
{[\text { 完全 }+(\text { 能 } \mid \text { 能够|可以|没有 })]+(\operatorname{Prep}+\mathrm{N})+(\text { 不 } \mid \text { 不受 } \mid \text { 没 }} \\
\text { 有 })+(\mathrm{V})+(\mathrm{Adj})+(\mathrm{N})\end{array}$ & $\begin{array}{l}\text { [Degree: thorough] } \\
\text { solutions }\end{array}$ \\
\hline 7 & 18 & $\begin{array}{l}\mathrm{N} \mid \mathrm{NP}+[\mathrm{V}+\text { 完全}+(\text { Prep+N)] | [完全+(Prep+N)] | [(Prep+N | } \\
\mathrm{NP})+ \text { 完全+(是 })]+(\mathrm{V})+(\text { Adj })+(\mathrm{N})\end{array}$ & $\begin{array}{c}\text { [Contrast: all] } \\
\text { positive development }\end{array}$ \\
\hline 8 & 18 & $\begin{array}{l}\mathrm{N} \mid \mathrm{NP}+(\text { 把 } \mid \text { 使 }+\mathrm{Adj}+\mathrm{N}) \mid(\text { 不 } \mid \text { 不能 } \mid \text { 没有 })+(\operatorname{Prep}+\mathrm{N})+[\text { 完全 }+(\text { 是 } \mid \\
\text { 不能 })] \mid[(\text { 是 })+\text { 完全 }]+[(\operatorname{Prep}+\mathrm{N} \mid \mathrm{NP})+\mathrm{V}]|[(\operatorname{Adj})+(\mathrm{N})]| \\
{[\mathrm{V}+(\mathrm{Adj})+\mathrm{N}]}\end{array}$ & $\begin{array}{l}\text { [Scope: all] } \\
\text { bad results }\end{array}$ \\
\hline 9 & 14 & $\begin{array}{l}(\mathrm{N})+(\text { 是|不能 } \mid \text { 把 }+A d j+N)+\text { 完全 }+(\text { 可以能|不是 })+A d j|N P| \\
{[(\text { Prep })+V]|[V+(A d j)+N \mid N P]|[\text { Prep+是 }+ \text { Adj }]}\end{array}$ & $\begin{array}{c}\text { [Scope: all] } \\
\text { positive development }\end{array}$ \\
\hline 10 & 9 & $(\mathrm{~N} \mid \mathrm{NP})+[($ 没有|能否 $)+\mathrm{V}] \mid[\mathrm{V}+($ 不|没有 $)] \mid$ 要 + 完全 & $\begin{array}{c}\text { [Scope: all] } \\
\text { Subjective descriptions }\end{array}$ \\
\hline 11 & 6 & $(\mathrm{~N})+(\operatorname{Prep}+\mathrm{NP}) \mid \mathrm{V}+($ 是 $)+$ 完全 $+\operatorname{Adj}|[\operatorname{Adj}+\mathrm{N}]|[\mathrm{V}+(\mathrm{N})]$ & $\begin{array}{l}\text { [Contrast: all] } \\
\text { bad results }\end{array}$ \\
\hline
\end{tabular}

In this table, brackets refer to optional components, square brackets to fixed structures, and vertical lines to replaceable lexis, word class or syntactic structures. It is arranged in descending order concerning the configurations' occurrences. In configuration 1, the subject is inanimate in most cases, such as “注意力’ (zhuyili: attention), ‘筹备” (choubei: arrangement), “描述’ (miaoshu: description), “天” (tian: heaven), “弱点’ (ruodian: shortcoming), ‘气味” (qiwei: smell), '范围' (fanwei: scope), etc. When it is followed by notional verbs, the behavior pattern to some extent will affirm the accidents caused by the actions. For example, the phrase ‘不完全取决于身体素质” (bu wanquan qujue yu shenti sushi, which means not completely depend on physical fitness) emphasizes the object '身体素质'. When it collocates with link verbs such as ‘是' or modal verbs such as ‘能”, ‘能够”, “可能”, ‘可以’, etc., the behavior pattern will be rather flexible since they can either be the core's right collocates or left collocates, and meanwhile these words 
amplify the content of subjects or objects. For instance, the intensifier in “完全是社里自己的钱” (wanuqan shi sheli zijide qian, which means it's all the community's own money) explains the amount of money. '完全' in this configuration thus has a semantic preference for events, phenomena, weather and experiments, which shares the prosody of describing these things objectively. Compared with configuration 1, the collocation features in configuration 2 and configuration 3 change a lot. For example, the semantic field of configuration 2 is about concepts (“泛化”, “坏死”, ‘化身’), society (“《国民政府建国大纲》’, ‘伦理规范”, “发展阶段”), judgement (“正确”, ‘确当”, ‘错误’), mood (‘心 情'), etc. And its main feature is that it only describes the hard facts without any comments. Configuration 3 is used to make comparations, where comparable adjectives have a high frequency when collocated with '完全', such as ‘相同' (xiangtong: same), “一样' (yiyang: identical), “不同'(butong: different), ‘相反' (xiangfan: opposite). Although adjectives are likely to reflect writers' true feelings, the co-text information in this configuration demonstrates the comparison is made on the surface features and that there are no personal attitudes. Configuration 10 is a little novelty since it applies to science disciplines with technical items and structures. For example, the position of '完全' is no longer in the start or the middle of sentences but in the end when the word modifies verbs, which shows that all the substances reacted in the experiment. Sinclair (1996:86) claimed that the internal variations of co-selection would disappear as semantic features became of abstraction and generalization. To sum up, the four configurations aforementioned share a same semantic prosody, that is, prosody of subjective descriptions to objects, states or experimental phenomena. And that's also why they become one Meaning-Shift unit.

Similarly, configuration 4, configuration 7 and configuration 9 are one Meaning-Shift unit, which indicates that people or things will grow towards a positive direction when '完全' collocates with positive word items, such as '新的” (xinde: new), “发生影响’ (fasheng yingxiang: having impact, in Chinese this phrases normally refers to positive influence), “不庈其烦” (buyanqifan: patient), ‘快乐’ (kuaile: joyful), ‘陶醉’ (taozui: enchanted) and so on. Besides, ‘完 全' will appear in negative structures or transitional complex sentences as well when it is assigned to give credit for the significance of what is happened. Configuration 5, Configuration 8 and Configuration 11 are the third Meaning-Shift unit, where the phraseological features are very unique in that their collocates hold negative connotations like '失望' (shiwang: disappointed), ‘悲剧’ (beiju: tragedy), ‘荒谬' (huangmiu: absurd), ‘仇敌’ (choudi: foe), ‘不能相容’ (buneng xiangrong: incompatible). And their semantic prosody is that it will have bad results, which are achieved from three aspects, namely degree, scope and contrast. In configuration 6, the core '完全' has a very high cooccurrence with phrases like ‘需要' (xuyao: should), “当作’ (dangzuo: take...as), “必要的’ (biyaode: necessary), ‘须” (xu: must), etc., whose semantic prosody is to put forward solutions to existing problems. Because only this configuration has such prosody, it is considered as a new Meaning-Shift unit by its own.

\section{Meaning-shift Unit}

From the above section, we conclude that the Chinese intensifier wanquan has four types of semantic prosody, which are to describe objects, states or experimental phenomena, to develop towards positive directions, to get bad results, and to provide solutions. Since semantic prosody is the key factor to Meaning-Shift unit, we divide these configurations into four groups. Thus, configuration 1, configuration 2, configuration 3 and configuration 10 belong to one meaning unit, which is to describe objects, states or experimental phenomena. Among the four configurations, configuration 1 occupies the highest position in terms of frequency, 119 times, so it is identified as the canonical form while the other three are the variant forms. Likewise, configuration 4, configuration 7 and configuration 9 make up another Meaning-Shift unit, having the prosody of developing towards positive directions, among which configuration 4 occupies the canonical form. Configuration 5, configuration 8 and configuration 10 have the meaning of getting bad results, therefore they constitute a third Meaning-Shift unit, whose canonical form is configuration 5. Lastly, configuration 6 per se becomes the last Meaning-Shift unit because there is no other configuration sharing the semantic prosody of providing solutions. The more details are in Table II. 
TABLE II.

MEANING SHIFT UNITS OF ‘完全’ (WANQUAN)

\begin{tabular}{|c|c|c|}
\hline \multicolumn{2}{|c|}{ Meaning Shift Unit } & Configuration \\
\hline \multirow{4}{*}{ MSU 1} & $\begin{array}{l}\text { Canonical } \\
\text { form }\end{array}$ & $\begin{array}{l}(\text { Adj })+(N)+(\text { 不没有 } \mid \text { 几乎 })+[(\text { 是|能|能够|可能 })+\text { 完全 }] \mid[(\text { 是 })+\text { 完全 }(\text { 地 })+(\text { 是|能|能够|可以 } \\
\text { 不会|没有 })]+[(\text { 被 })+(N P)+V] \mid[(P r e p)+(N \mid N P)+(V)+(A d j)+(N \mid N P)]\end{array}$ \\
\hline & Variant 1 & 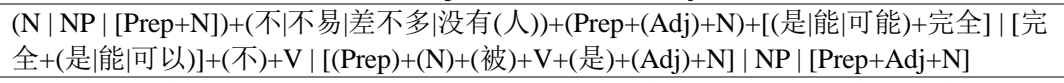 \\
\hline & Variant 2 & $\begin{array}{l}\text { (NP)+[(不 } \mid \text { 没有|可以)] | [(Prep+(N|NP))]+[(是)+(不|不会|不能|可能)+完全] | [完全+(是| } \\
\text { 不)]+(Prep+N)+Adj }|N| N P|[V+(N)]|[A d j+N \mid N P+(V)]\end{array}$ \\
\hline & Variant 3 & $(\mathrm{~N} \mid \mathrm{NP})+[($ 没有|能否 $)+\mathrm{V}] \mid[\mathrm{V}+($ 不|没有 $)]$ |要+完全 \\
\hline \multirow{3}{*}{ MSU 2} & $\begin{array}{l}\text { Canonical } \\
\text { form }\end{array}$ & $\begin{array}{l}(\mathrm{N} \mid \mathrm{NP})+[(\text { 不 } \mid \text { 不是|没有|并非|可以 })] \mid[((\text { 使 })+\operatorname{Prep}+\mathrm{N})]+(\mathrm{V})+[(\text { 是|可能 })+\text { 完全 }+(\text { 没有 })] \mid[\text { 完 } \\
\text { 全+(是|没有 })]+(\operatorname{Prep}+\mathrm{N})+[(\text { 可以|能够|有机会|有可能 })+\mathrm{V}+(\text { Adj })+(\mathrm{N} \mid \mathrm{NP})]|[(\mathrm{Adj})+\mathrm{N} \mid \mathrm{NP}]| \\
\text { Adj }\end{array}$ \\
\hline & Variant 1 & $\begin{array}{l}\mathrm{N} \mid \mathrm{NP}+[\mathrm{V}+\text { 完全+(Prep+N)] | [完全+(Prep+N)] | [(Prep+N | NP)+完全 } \\
+(\text { 是 })]+(\mathrm{V})+(\text { Adj })+(\mathrm{N})\end{array}$ \\
\hline & Variant 2 & $\begin{array}{l}(\mathrm{N})+(\text { 是|不能 } \mid \text { 把+Adj+N)+完全+(可以|能|不是)+Adj | NP | [(Prep)+V] | [V+(Adj)+N | NP] | } \\
{[\text { Prep+是+Adj] }}\end{array}$ \\
\hline \multirow{3}{*}{ MSU 3} & $\begin{array}{l}\text { Canonical } \\
\text { form }\end{array}$ & $\begin{array}{l}(\mathrm{N} \mid \mathrm{NP})+(\text { Prep+(Adj)+(N | NP))+(不不至|未)+(是|能|能够)+[(V+N+Prep+(Adj)+N)] } \mid(\mathrm{V})+ \\
\text { 完全(地)+(没有|不|可以)+(被| [把+N+Prep+N])+(V)+(Adj)+(N|NP) }\end{array}$ \\
\hline & Variant 1 & $\begin{array}{l}\mathrm{N} \mid \mathrm{NP}+(\text { 把|使+Adj+N)|(不不能|没有)+(Prep+N)+[完全+(是|不能 })] \mid[(\text { 是 })+\text { 完 } \\
\text { 全]+[(Prep+N|NP)+V] } \mid[(\text { Adj })+(N)] \mid[V+(\text { Adj })+N]\end{array}$ \\
\hline & Variant 2 & $(\mathrm{~N})+(\operatorname{Prep}+\mathrm{NP}) \mid \mathrm{V}+($ 是 $)+$ 完全+Adj $|[\operatorname{Adj}+\mathrm{N}]|[\mathrm{V}+(\mathrm{N})]$ \\
\hline MSU 4 & $\begin{array}{l}\text { Canonical } \\
\text { form }\end{array}$ & $\begin{array}{l}(\mathrm{N})+[(\operatorname{Prep}+(\mathrm{N} \mid \mathrm{NP}))+[(\text { 能够|是|不|末|不能 })+\text { 完全 }+(\text { 能 })+(\mathrm{V})] \mid[\text { 完全 }+(\text { 能|能够|可以|没 } \\
\text { 有 })]+(\operatorname{Prep}+\mathrm{N})+(\text { 不|不受|没有 })+(\mathrm{V})+(\mathrm{Adj})+(\mathrm{N})\end{array}$ \\
\hline
\end{tabular}

This table demonstrates that every Meaning-Shift unit encompasses one canonical form which is essential and several potential variants according to their semantic prosody. One point to note is that some MSUs only have one canonical form like MSU 4 in this case. Such forms including canonical forms and variant forms can be called paraphrasable family as well (Cheng et al., 2008; Gao and Wei, 2017). The configurations which conform to the same local grammar will share a unit of meaning (Sinclair, 2010; Gao and Wei, 2017). In other words, we could identify the meaning unit from the observed configurations by their local grammar. This echoes Hunston's claim that each local grammar describes one meaning or one function (Hunston, 2002). Different from general grammar, local grammar is a micro-description to language which deals with special linguistic phenomena in the process of using language in authentic contexts ( $\mathrm{Li}, 2018: 52$ ), the advantage of which is to bring syntagmatic and paradigmatic relations closer. In this paper, the intensifier wanquan has four meaning units, thus corresponding to four local grammars. Since it's a complex and huge project, we will leave this question in another paper.

\section{CONCLUSION}

The syntagmatic relation and the paradigmatic relation become significantly salient in concordance lines from the perspective of corpus linguistics, because the former provides evidence of repeated structural patterns and the latter of linear combinations, which helps interpret meaning in a comprehensive way (Stubbs, 2009:131). It is suggested that people normally select certain phrases and grammars to express their meaning, but the appropriate way to analyze the unit of meaning remains a tough question for the contemporary philologists. Luckily, the MSU theory provides an effective way to answer it. This study explores the Meaning-Shift units of wanquan, a Chinese intensifier in the CNC. One of the significant findings is that the word has four meaning units determined by the types of semantic prosody, which in turn are to describe objects, states or experimental phenomena, to develop towards positive directions, to get bad results, and to provide solutions. What's also important is that most of the canonical forms have two or three variants except one having none, and that each Meaning-Shift unit has one local grammar, making lexis, grammar and meaning structuralized in a systematic way. In doing so, this corpus-based study not only provides a fresh perspective such as studying intensifiers to supplement the empirical studies on Meaning-Shift unit, but also encourages other countries to apply this theory into their indigenous languages.

\section{REFERENCES}

[1] Allen, C. (2005). A Local Grammar of Cause and Effect: A Corpus-driven Study. Birmingham: University of Birmingham.

[2] Altenberg, B. (1991). Amplifier collocations in spoken English. In Johansson, S. \& Stenström, A. (Eds.). English Computer Corpora. Berlin: Mouton de Gruyter.

[3] Barnbrook, G. (2002). Defining Language: A Local Grammar of Definition Sentences. Amsterdam/Philadelphia: John Benjamins.

[4] Bednarek, M. (2008a). Emotion Talk across Corpora. London: Palgrave.

[5] Bednarek, M. (2008b). Semantic preference and semantic prosody re-examined. Corpus Linguistics and Linguistic Theory, 4(2), 119-139. 
[6] Bolinger, D. (1972). Degree Words. The Hague: Mouton.

[7] Cheng, W., Greaves, C., Sinclair, J. \& Warren, M. (2008). Uncovering the extent of the phraseological tendency: Towards a systematic analysis of concgrams. Applied Linguistics, 30(2), 236-252.

[8] Crystal, D. (2011). A Dictionary of Linguistics and Phonetics. British: Blackwell Publishing.

[9] Gao, Ge. \& Wei, Naixing. (2017). Meaning-Shift unit: Implications and the analytical procedure. Teaching Languages and Their Teaching, 6, 12-21.

[10] Hunston, S. (2002). Corpora in Applied Linguistics. Cambridge: Cambridge University Press.

[11] Hunston, S. \& Sinclair, J. (2000). A local grammar of evaluation. In Hunston. S. \& Thompson, G. (Eds.). Evaluation in Text: Authorial Stance and the Construction of Discourse. New York: Oxford University Press.

[12] Ito, R. \& Tagliamonte, S. (2003). Well weird, right dodgy, very strange, really cool: Layering and recycling in English intensifiers. Language in Society, 32(2), 257-279.

[13] Kennedy, G. (2003). Amplifier collocations in the British National Corpus: Implications for English language teaching. TESOL Quarterly, 37(3), 467-487.

[14] Kennedy, C. \& McNally, L. (2005). Scale structure, degree modification, and the semantics of gradable predicates. Language, 81(2), 345-381.

[15] Labov, W. (1984). Intensity. In Schiffrin, D (Ed.). Meaning, Form, and Use in Context: Linguistic Applications. Washington: Georgetown University Press.

[16] Lakoff, R. (1975). Language and Women's Place. New York: Harper and Row.

[17] Li, Wenzhong. (2018). On the theoretical framework of phrases. Foreign Language Teaching and Research, 50(1), 49-59.

[18] Liang, Maocheng., Li, Wenzhong. \& Xu, Jiajin. (2010). Using Corpora: A Practical Coursebook. Beijing: Foreign Language and Research Press.

[19] Louw, B. (1993). Irony in the text or insincerity in the writer? The diagnostic potential of semantic prosodies. In Baker, M., Francis, G. \& Tognini-Bonelli, E. (Eds.). Text and Technology: In Honour of John Sinclair. Amsterdam/Philadelphia: John Benjamins Publishing Company.

[20] Lu, Jun. \& Wu, Qian. (2019). A study of meaning shift in phraseological units: Evidence from Chinese and English popular phrases. Modern Foreign Languages, 5, 1-13.

[21] Morley, J. \& Partington, A. (2009). A few frequently asked questions about semantic-or evaluative-prosody. International Journal of Corpus Linguistics, 14(2), 139-158.

[22] O'Halloran, K. (2007). Critical discourse analysis and the corpus-informed interpretation of metaphor at the register level. Applied Linguistics, 28(1), 1-24.

[23] Partington, A. (1993). Corpus evidence of language change-The case of the intensifier. In Baker. M., Francis, G. \& Tognini-Bonelli, E. (Eds.). Text and Technology. Amsterdam: John Benjamins.

[24] Partington, A. (2004). "Utterly content in each other's company": Semantic prosody and semantic preference. International Journal of Corpus Linguistics, 9(1), 131-156.

[25] Quirk, R., Greenbaum, S., Leech, G. \& Svartvik, J. (1985). A Comprehensive Grammar of the English Language. London: Longman.

[26] Shao, Bin., Wang, Wenbin. \& Huang, Danqing. (2017). A collostructional analysis of English amplifiers and the visualization of their semantic distances. Foreign Language Teaching and Research, 49(3), 379-391.

[27] Sinclair, J. (1987). Collocation: A progress report. In Steele. R. \& Threadgold, T. (Eds.). Language Topics: Essays in Honour of Michael Halliday. Amsterdam: John Benjamins.

[28] Sinclair, J. (1991). Corpus, Concordance, Collocation. Oxford: Oxford University Press.

[29] Sinclair, J. (1996). The search for units of meaning. Textus, 1, 75-106.

[30] Sinclair, J. (2004). Trust the Text. London: Routledge.

[31] Sinclair, J. (2007). Collocation reviewed - new (manuscript). Italy: Tuscan Word Centre.

[32] Sinclair, J. (2008). The phrase, the whole phrase, and nothing but the phrase. In Granger. S. \& Meunier, F. (Eds.). Phraseology: An Interdisciplinary Perspective. Amsterdam/Philadelphia: John Benjamins Publishing Company.

[33] Sinclair, J. (2010). Defining the definiendum. In Schryver, G. (Ed.). A Way with Words: Recent Advances in Lexical Theory and Analysis. Kampala: Menha Publishers.

[34] Stubbs, M. (2009). The search for units of meaning: Sinclair on empirical semantics. Applied Linguistics, 30(1), 115-137.

[35] Su, H. (2015). Judgement and Adjective Complementation Patterns in Biographical Discourse: A Corpus Study. Birmingham: University of Birmingham.

[36] Su, Yujie. (2016). Corpus-based comparative study of intensifiers: quite, pretty, rather and fairly. Journal of World Languages, $3(3), 224-236$.

[37] Tagliamonte, S. (2008). So different and pretty cool! Recycling intensifiers in Toronto, Canada. English Language and Linguistics, 12(2), 361-394.

[38] Tagliamonte, S. \& Roberts, C. (2005). So weird; so cool; so innovative: The use of intensifiers in the television series Friends. American Speech, 80(3), 280-300.

[39] Tao, H. (2007). A corpus-based investigation of absolutely and related phenomena in spoken American English. Journal of English Linguistics, 35(1), 5-29.

[40] Wei, Naixing. (2012). Theory of co-selection and the corpus-driven phraseology. Journal of PLA University of Foreign Languages, 35(1), 1-6.

[41] Wray, A. (2012). What do we (think we) know about formulaic language? An evaluation of the current state of play. Annual Review of Applied Linguistics, 32, 231-254.

[42] Xiao, R. \& Tao, H. (2007). A corpus-based sociolinguistic study of amplifiers in British English. Sociolinguistic Studies, 1(2), 241-273. 
Guobing Liu was born in Henan, China. He received the doctoral degree in corpus linguistics and computational linguistics in 2013. In recent years, he published several books and more than thirty academic papers in the key journals both home and abroad. His academic interests include corpus linguistics and foreign language teaching.

Xiaolian Zhang was born in Henan, China. She will receive the master's degree in Foreign Languages and Literature in 2021. Now she studies at the Faculty of International Studies, Henan Normal University. She is interested in meaning and her master's thesis is also related to it. Her academic interests are mainly corpus linguistics. 